\title{
Mediasi Profitabilitas Dalam Menilai Hubungan Antara Manajemen Modal Kerja dan Nilai Perusahaan
}

\author{
Mohammad Arief \\ Jurusan Manajemen Universitas Trunojoyo Madura \\ Jl. Raya Telang, Kamal, Bangkalan, 69162, Indonesia
}

\section{Info Artikel}

Keywords:

Firm Value; Profitability; and

Working Capital Management.

Kata Kunci:

Manajemen Modal Kerjal; Nilai

Perusahaan; dan Profitabilitas

ISSN (print): 2598-7763

ISSN (online): 2598-7771

$\triangle$ Corresponding Author:

Mohammad Arief:

Tel. / Fax. 08123227266

E-mail:papi.arief@gmail.com

\begin{abstract}
Abtract
This study aims to examine the effect of working capital management on firm value in cement companies listed on the Indonesia Stock Exchange (IDX) in the 2012-2017 period, either directly or indirectly through profitability. This study uses a quantitative approach. Sampling using saturated sampling method. There are six cement companies that meet the categories as samples. Furthermore, Partial Least Square (PLS) is used for analysis and hypothesis testing for testing the profitability variable as a mediation. The results show that working capital that is managed effectively and efficiently can improve financial performance so as to increase firm value. The results of the mediation test show that profitability positively mediates the effect of working capital management on firm value. This explains that the implementation of good working capital management can increase the profit generated by the company so that the company value increases, which ultimately investors respond positively.
\end{abstract}

Citation: Arief, M. (2020). Mediasi Profitabilitas Dalam Menilai Hubungan Antara Manajemen Modal Kerja Dan Nilai Perusahaan. AFRE Accounting and Financial Review. 3(2): 126-135

\begin{abstract}
Abstraks
Penelitian ini bertujuan untuk menguji pengaruh antara manajemen modal kerja terhadap nilai perusahaan pada perusahaan semen yang terdaftar di Bursa Efek Indonesia (BEI) pada periode 2012-2017, baik secara langsung maupun tidak langsung melalui profitabilitas. Penelitian ini menggunakan pendekatan kuantitatif. Pengambilan sampel menggunakan metode sampel jenuh. Terdapat 6 perusahaan semen yang memenuhi kategori sebagai sampel. Selanjutnya, Partial Least Square (PLS) digunakan untuk analisis dan pengujian hipotesis untuk pengujian variabel profitabilitas sebagai mediasi. Hasil penelitian menunjukkan bahwa modal kerja yang dikelola secara efektif dan efisien dapat meningkatkan kinerja keuangan sehingga dapat meningkatkan nilai perusahaan. Hasil pengujian mediasi menunjukkan bahwa profitabilitas memediasi secara positif pengaruh antara manajemen modal kerja terhadap nilai perusahaan. Hal ini menjelaskan bahwa pelaksanaan manajemen modal kerja yang baik dapat meningkatkan profit yang dihasilkan oleh perusahaan sehingga nilai perusahaan pun meningkat yang akhirnya investor merespon positif.
\end{abstract}

JEL Classification: G20, G21

DOI: $h$ ttps://doi.org/10.26905/afr.v3i2.5807

\section{PENDAhULUAN}

Secara konvensional penilaian kinerja keuangan perusahaan berfokus pada keputusan keuangan jangka panjang seperti keputusan investasi, struktur modal, deviden, dan sebagainya (Chowdhury et al., 2018). Disamping keputusan jangka panjang sebenarnya keputusan jangka pendek seperti aktiva lancar adalah merupakan elemen penting dari total ak-tiva yang perlu untuk dianalisis dan dikelola secara berhati-hati (Sin et al., 2017). Dikatakan bahwa aktiva lancar yang digunakan untuk kegiatan operasional perusahaan tidak ku-rang dari 1 (satu) tahun dan selalu dikaitkan de-ngan likuiditas perusahaan, 
efisiensi kegiatan operasional, tingkat risiko, tingkat profitabilitas (Jakpar et al., 2017). Dikatakan juga bahwa aktiva lancar diibaratkan sebagai darah kehidupan (lifeblood) perusahaan (Afrifa \& Padachi, 2016).

Modal kerja merupakan salah satu bentuk investasi yang tergolong dalam keputusan keuangan jangka pendek dimana perusahaan menggunakannya untuk membiayai kegiatan operasional sehari-hari dalam satu tahun (Cumbie \& Donnellan, 2017). Dijelaskan lebih lanjut oleh Cumbie \& Donnellan (2017) definisi modal kerja selalu melibatkan penggunaan aset lancar dan hutang lancar karena manajemen modal kerja melibatkan dua hal dasar yaitu menentukan jumlah modal kerja yang sesuai dan bagaimana modal kerja dibiayai. Komponen modal kerja terdiri dari kas yang dibutuhkan dalam operasi, piutang, persediaan, hutang yang dibayarkan kepada pemasok atau hutang usaha dan hutang akrual (Afrifa \& Padachi, 2016). Namun, juga ada pendapat yang mengatakan bahwa komponen modal kerja yang paling utama adalah piutang, persediaan dan hutang usaha, sedangkan kas tidak termasuk karena dianggap termasuk dalam komponen siklus pembiayaan (Sunday, 2017).

Profitabilitas merupakan hasil akhir dari sejumlah kebijakan dan keputusan yang dilakukan oleh perusahaan dengan menunjukkan gabungan efek-efek dari likuiditas, manajemen aktiva, dan hutang pada hasil-hasil operasi (Alsartawi, 2019). Profitabilitas dapat dinyatakan sebagai kemampuan perusahaan untuk menghasilkan laba dari kegiatan operasional melalui penggunaan aset-asetnya (Alsartawi, 2019). Profitabilitas merupakan cerminan dari kinerja keuangan suatu perusahaan (Putri et al., 2018; Chasbiandani et al., 2019; Fristiani et al., 2020). Profitabilitas berbeda dengan margin perusahaan. Jika margin menunjukkan rasio pendapatan terhadap volume bisnis seperti penjualan atau produksi, profitabilitas merupakan suatu rasio laba terhadap modal yang harus diinvestasikan untuk menghasilkan laba (Alsartawi, 2019).

Nilai perusahaan menunjukkan nilai sekarang dari arus kas yang diharapkan, diskonto pada tingkat yang mencerminkan baik risiko proyek perusahaan maupun bauran pembiayaan yang digunakan untuk membiayai proyek tersebut (Rasyid, et.al., 2018). Manajemen yang bertujuan untuk memaksimalkan nilai perusahaan harus mengetahui hubungan nilai yang diharapkan dengan tiga keputusan keuangan utama yaitu investasi, pembagian di-viden dan pembiyaan
(Cheryta et al., 2018). Pada dasarnya nilai perusahaan mencerminkan dampak dari tiga keputusan keuangan yang dilakukan oleh perusahaan yang bersangkutan. Ada beberapa pendekatan dalam menentukan nilai perusahaan. Salah satu pendekatan yang mudah dilakukan adalah melalui penilaian relatif atau melalui nilai pasar. Nilai pasar memberikan indi-kasi bagaimana investor menanggapi tentang ki-nerja masa lalu dan prospek perusahaan di masa yang akan datang (Lin et al., 2016).

Modal kerja harus dikelola dengan baik dan disesuaikan dengan kebutuhan perusahaan. Kebutuhan modal kerja akan berbeda-beda tergantung karakteristik perusahaan (Ukaegbu, 2014). Modal kerja perusahaan di bidang industri, ritel dan jasa, masing-masing akan berbeda satu sama lain. Perusahaan di bidang industri biasanya lebih menitikberatkan pada pembelian bahan baku dengan rentang pembayaran kredit yang panjang dan terdapat proses produksi, sedangkan perusahaan yang bergerak di perdagangan eceran atau retail lebih membeli persediaan barang yang besar untuk dijual kembali, tetapi dengan tingkat hutang yang rendah kepada pemasok. Berbeda pula dengan perusahaan di bidang jasa yang membeli persediaan tanpa melakukan proses produksi. Menentukan modal kerja sesuai dengan kebutuhan merupakan tugas utama da-ri manajermanajer perusahaan yang terlibat dalam manajemen modal kerja.

Secara teori, manajemen modal kerja dapat diartikan bagaimana perusahaan mengelola modal kerjanya yang melibatkan pengelolaan aset lancar dan hutang lancar (Lyngstadaas \& Berg, 2016). Manajemen modal kerja dapat dikaitkan dengan profitabilitas dan nilai perusahaan karena terkait dengan pencapaian tujuan utama manajemen keuangan (Shah \& Arif, 2018). Teori manajemen modal kerja pada dasarnya berfokus melakukan trade off antara kemampuan menghasilkan laba (profitabilitas) dan risiko yang berhubungan dengan tingkat aset lancar dan hutang lancar (Abuzayed, 2012). Tujuan utama manajemen modal kerja adalah memaksimalkan nilai kekayaan pemegang saham (Lyngstadaas \& Berg, 2016). Lebih lanjut Lyngstadaas \& Berg (2016) menjelaskan bahwa manajemen modal kerja yang baik seharusnya dapat mengurangi kebutuhan investasi dalam modal operasi sehingga arus kas bebas dan nilai perusahaan akan meningkat. Dengan demikian, perusahaan perlu menerapkan efisiensi manajemen modal kerja agar dapat menekan biaya investasi yang dikeluarkan sehingga laba 
akan semakin meningkat. Meningkatnya laba yang dihasilkan perusahaan karena adanya upaya efisiensi manajemen modal kerja juga menyebabkan nilai perusahaan meningkat (Almeida \& Junior, 2014).

Penerapan manajemen modal kerja suatu perusahaan dapat diukur melalui konsep siklus kas (Rasyid et al., 2018). Lebih lanjut Rosyeni Rasyid et al. (2018) menjelaskan bahwa siklus kas didefinisikan sebagai jumlah hari ketika perusahaan membayar pembelian persediaan bahan baku hingga perusahaan memperoleh kas dari penjualan produk jadi. Perusahaan dengan manajemen modal kerja yang baik memiliki siklus kas yang lebih pendek, artinya, perusahaan dapat meminimalkan waktu diantara pengeluaran kas untuk bahan baku dan penagihan kas dari penjualan yang dilakukan (Caballero et al., 2014). Pengukuran yang paling sering digunakan dalam penelitian manajemen modal kerja adalah siklus perubahan kas atau cash conversion cycle (Afrifa \& Padachi, 2016). Afrifa \& Padachi (2016) menjelaskan lebih lanjut, selain menggunakan siklus konversi kas, periode penagihan piutang (days of sales outstanding), periode konversi persediaan (days of sales inventory) dan periode pembayaran hutang (days of payable) juga dapat digunakan untuk mengukur manajemen modal kerja terkait pengelolaan piutang usaha, persediaan dan hutang usaha. Dimana ketiga pengukuran tersebut merupakan komponen dari siklus konversi kas.

Sesuai dengan agency theory dan signaling theory, antara manajemen modal kerja, profitabilitas dan nilai perusahaan terdapat hubungan yang saling mempengaruhi satu sama lain (Brigham \& Houston, 2018). Dimana tujuan utama dari manajemen modal kerja adalah memaksimalkan nilai perusahaan (Shah \& Arif, 2018). Efisiensi pada manajemen modal kerja selain dapat meningkatkan profitabilitas juga dapat meningkatkan nilai perusahaan (Rasyid et al., 2018). Dalam penelitian juga ditemukan bahwa penggunaan jumlah modal kerja yang berlebih dapat menurunkan laba dan juga menurunkan nilai perusahaan yang diberikan oleh pasar (Almeida \& Junior, 2014). Jika beberapa pernya-taan tersebut dihubungkan dengan konsep (Fama \& French, 2000) terkait dengan hubungan profitabilitas dengan nilai perusahaan, dapat diambil suatu hubungan baru bahwa peningkatan ke-mampuan perusahaan dalam menghasilkan laba karena didukung oleh efisiensi pada manajemen modal kerja sehingga dapat meningkatkan nilai perusahaan.
Penelitian ini dilakukan pada perusahaan manufaktur sektor industri dasar dan kimia dengan sub sektor semen. tingkat konsumsi semen di Indonesia mengalami kenaikan dari periode ke periode yang menunjukkan bahwa hasil industri semen berkembang pesat di Indonesia. Dimana hal ini sesuai dengan program pemerintah untuk semua daerah di Indonesia yang menunjukkan peningkatan luar biasa dalam pembangunan infrastruktur, kecuali Kalimantan. Hal ini karena bergulirnya realisasi anggaran pemerintah untuk infrastruktur, pembangunan sejuta rumah serta anggaran pembangunan pemerintah daerah (www.industri.bisnis.com, diakses tanggal $1 \mathrm{Mei}$ 2019).

Dengan meningkatnya konsumsi semen dalam negeri ini membuat produksi semen juga meningkat, yang mana persediaan yang dimiliki perusahaan berumur tidak lebih dari satu tahun, sehingga perhatian perusahaan terhadap pengelolaan modal kerjanya lebih tinggi daripada perusahaan manufaktur yang lain. Hal ini menunjukkan bahwa modal kerja sebagai komponen penting dalam industri semen di Indonesia memiliki karakteristik khusus dibandingkan dengan industri lainnya. Karakteristik khusus ini dapat dilihat dari sisi jumlahnya yang cukup besar yang ditunjukkan dengan jumlah aktiva lancarnya yang lebih besar dibanding dengan aktiva tetapnya.

Iklim usaha yang kondusif memberikan kesempatan bagi perusahaan untuk tumbuh. Perusahaan di sektor industri semen di Indonesia tentu menerima dampak yang signifikan karena sektor ini dipengaruhi oleh daya beli masyarakat yang dipengaruhi oleh kondisi tingkat pertumbuhan PDB, suku bunga dan kinerja ekonomi makro negara (Moeljadi, 2017). Dengan kondisi eksternal yang sangat mendukung, perusahaan di sektor industri semen Indonesia berupaya untuk memanfaatkan peluang yang ada agar dapat memperoleh laba dengan meningkatkan penjualannya, rata-rata tingkat penjualan perusahaan sektor semen meningkat lebih kurang satu triliun setiap tahunnya dari tahun 2012 hingga tahun 2017. Namun, biasanya perusahaan membutuhkan modal kerja yang lebih besar ketika mengembangkan bisnisnya terutama untuk meningkatkan penjualannya (Sunday, 2017). Hal tersebut juga terjadi pada perusahaan di industri semen. Industri semen

Perusahaan yang bergerak pada industri Semen merupakan perusahaan semen adalah perusahaan manufaktur dengan skala produksi yang besar sehingga membutuhkan modal kerja yang 
besar pula. Profitabilitas perusahaan semen cenderung naik, seiring dengan pertumbuhan penjualan yang meningkat. Nilai saham dari perusahaan semen juga ikut meningkat.

Days of Sales Outstanding (periode perubahan piutang), Days of Sales Inventory (periode perubah-an persediaan), Days of Payable (periode pemba-yaran hutang) digunakan sebagai variabelvari-abel yang mewakili manajemen modal kerja. Return on Assets (ROA) digunakan sebagai proksi dari variabel profitabilitas, sedangkan Tobin's $Q$ digunakan sebagai proksi dari variabel nilai perusahaan. Variabel-variabel tersebut juga dipilih dengan merujuk pada pertimbangan penelitian terdahulu. Konsep siklus konversi kas merupakan pengukuran yang paling sering digunakan dalam penelitian (Afrifa \& Padachi, 2016) dan dapat mengukur manajemen modal kerja perusahaan secara komprehensif (Jakpar et al., 2017), tetapi penelitian ini berfokus pada komponen-komponennya. Penelitian ini bertujuan untuk menganalisis pengaruh modal kerja terhadap profitabilitas dan bagaimana profitabilitas memediasi modal kerja terhadap nilai perusahaan.

\section{PENGEMBANGAN HIPOTESIS}

Merujuk pada agency theory dan signaling theory, antara manajemen modal kerja, profitabilitas dan nilai perusahaan terdapat hubungan yang saling mempengaruhi (Brigham \& Houston, 2018). Dimana tujuan utama dari manajemen modal kerja adalah memaksimalkan nilai perusahaan (Shah \& Arif, 2018). Efisiensi pada manajemen modal kerja selain dapat meningkatkan profitabilitas juga dapat meningkatkan nilai perusahaan (Rasyid et al., 2018). Jika konsep tersebut dihubungkan dengan konsep (Fama \& French, 2000) terkait dengan hubungan profitabilitas dengan nilai perusahaan, dapat di-ambil suatu hubungan baru bahwa peningkatan kemampuan perusahaan dalam menghasilkan laba karena didukung oleh efisiensi pada manajemen modal kerja sehingga dapat meningkatkan nilai perusahaan.

Studi sebelumnya yang terkait dengan manajemen modal kerja telah dilakukan dalam berbagai model, yang menunjukkan pro dan kontra dari temuan penelitian, terutama dalam pengaruhnya terhadap kinerja keuangan. Secara empirik, teori yang menyebutkan efisiensi manajemen modal kerja dapat meningkatkan profitabilitas perusahaan didukung dengan temuan bahwa siklus konversi kas memiliki pengaruh negatif signifikan terhadap profitabilitas (Afrifa \& Padachi,
2016; Agha \& Mba, 2014; Jakpar et al., 2017; Sin et al., 2017; Ukaegbu, 2014). Hasil penelitian ini menunjukkan bahwa semakin efisien perusahaan mengelola modal kerjanya, semakin meningkatkan profitabilitas yang ditandai dengan semakin pendek siklus konversi kas. Berbeda dengan hasil penelitian lain yang menunjukkan hal sebaliknya bahwa siklus perubahan kas memiliki pengaruh positif signifikan terhadap profitabilitas (Enqvist, Graham, \& Nikkinen, 2014; Lyngstadaas \& Berg, 2016; Caballero et al., 2014; Wiyono, 2017) yang menunjukkan tidak efisiennya pengelolaan modal kerja suatu perusahaan. Namun, semakin lama siklus konversi kas mungkin dapat meningkatkan profitabilitas selama biaya peningkatan investasi modal kerja tidak lebih besar daripada manfaatnya (Afrifa \& Padachi, 2016). Berdasarkan penjelasan tersebut, hipotesis 1, 2 dan 3 dapat dirumuskan sebagai berikut:

$\mathrm{H}_{1}$ : Days Of Sales Outstanding memiliki pengaruh signifikan terhadap Profitabilitas

$\mathrm{H}_{2}$ : Days Of Sales Inventory memiliki pengaruh signifikan terhadap Profitabilitas

$\mathrm{H}_{3}$ : Days Of Payable memiliki pengaruh signifikan terhadap Profitabilitas

Days of Sales Outstanding (DSO) merupakan rata-rata waktu yang dibutuhkan perusahaan untuk mengubah piutang usaha menjadi kas dengan cara menagih piutang usaha dari pelanggannya sehingga perusahaan menerima kas dari penagihan tersebut. Semakin pendek days of sales outstanding, semakin pendek pula siklus perubahan kas. Days of sales outstanding diukur melalui jumlah piutang usaha perusahaan dibagi dengan penjualan bersih lalu hasil dari perhitungan tersebut dikalikan dengan 365. Hasil akhir penghitungan days of sales outstanding berupa data kontinyu dengan satuan hari.

Days of Sales Outstanding $=\frac{\text { Accoumt Recaivable }}{\text { Soles }} \times 365$

(Afrifa \& Padachi, 2016)

Days of Sales Inventory (DSI) merupakan rata-rata waktu yang diperlukan perusahaan untuk menjual persediaan barang jadinya. Semakin pendek days of sales inventory, semakin pendek siklus perubahan kas. Days of sales inventory diukur melalui jumlah total persediaan barang jadi perusahaan dibagi dengan harga pokok penjualan lalu hasil dari perhitungan tersebut dikalikan dengan 365. Hasil akhir penghitungan days of sales inventory berupa data kontinyu de-ngan satuan hari. 
Days of Sales Inventory $=\frac{\text { Inventory }}{\text { Cost of Sales }} \times 365$

(Afrifa \& Padachi, 2016)

Days of Payables (DOP) merupakan rata-rata waktu yang dibutuhkan untuk membeli bahan baku serta pembayarannya. Semakin panjang days of payables, semakin pendek siklus perubahan kasnya. Days of payables diukur melalui jumlah hutang usaha perusahaan dibagi dengan harga pokok penjualan lalu hasil dari perhitungan tersebut dikalikan dengan 365. Hasil akhir penghitungan days of payables berupa data kontinyu dengan satuan hari.

$$
\text { Days of Payables }=\frac{\text { Account Payables }}{\text { Cost of Sales }} \times 365
$$

(Afrifa \& Padachi, 2016)

Days of Payables (DOP) merupakan rata-rata waktu yang dibutuhkan untuk membeli bahan baku serta pembayarannya. Semakin panjang days of payables, semakin pendek siklus perubahan kasnya. Days of payables diukur melalui jumlah hutang usaha perusahaan dibagi dengan harga pokok penjualan lalu hasil dari perhitungan tersebut dikalikan dengan 365. Hasil akhir penghitungan days of payables berupa data kontinyu dengan satuan hari.

$$
\text { Days of Payables }=\frac{\text { Account Payables }}{\text { Cost of Sales }} \times 365
$$

(Afrifa \& Padachi, 2016)

Profitabilitas merupakan kemampuan perusahaan dalam menghasilkan laba dari kegiatan operasional. Profitabilitas diproksikan dengan meng-gunakan return on asset (ROA) yang dihitung melalui nett income dibagi dengan average total assets. Dimana average total assets diperoleh dari total aset awal tahun ditambah dengan total aset akhir tahun, lalu hasil penjumlahan tersebut dibagi dengan dua. Hasil akhir penghitungan ROA berupa data persentase.

$$
\text { Return On Asset }=\frac{\text { Net Income }}{\text { Average Total Assets }}
$$

(Afrifa \& Padachi, 2016)

Nilai perusahaan merupakan penilaian kinerja masa lalu dan prospek perusahaan di masa yang akan datang melalui pertimbangan manajemen modal kerja. Tobin's Q (TQ) dihitung melalui nilai pasar dari perusahaan dibagi dengan nilai buku aset dari perusahaan. Nilai pasar dari perusahaan dihitung melalui perkalian jumlah saham beredar dan harga saham. Hasil akhir penghitungan Tobin's Q berupa data persentase.

$$
\text { Tabin's } Q=\frac{\text { Market Value of The Firm }}{\text { Book Value of Firm }}
$$

(Rasyid et al., 2018)

Banyak penelitian yang membuktikan bahwa manajemen modal kerja yang efektif dan efisien dapat meningkatkan profitabilitas yaitu diantaranya Agha \& Mba (2014), Caballero, et al., (2014), Enqvist et al., (2014), Ukaegbu (2014), Afrifa \& Padachi (2016), Lyngstadaas \& Berg (2016), Jakpar et al., (2017), Sin et al., (2017), Wiyono (2017). Meskipun demikian, Abuzayed (2012), Yazdanfar \& Öhman (2014), (Sunday, 2017) menyatakan bah-wa manajemen modal kerja yang efektif dan efisien tidak berpengaruh terhadap profitabilitas. Dengan demikian dapat disimpulkan bahwa belum ada kejelasan mengenai hubungan relasional antara manajemen modal kerja dan profitabilitas.

Manajemen modal kerja dan profitabilitas mempunyai pengaruh yang positif terhadap nilai perusahaan (Almeida \& Junior, 2014; Cumbie \& Donnellan, 2017; Lin et al., 2016; Moeljadi, 2017; Rasyid et al., 2018; Sabrin, Sarita, Dedy \& Sujono, 2016; Shah \& Arif, 2018; Sudiyatno, Puspitasari, \& Sudarsi, 2017; Wasiuzzaman, 2015). Berdasarkan hubungan tersebut, maka pe-nelitian ini mengembangkan suatu model untuk memberikan solusi atas research gap tersebut dengan menempatkan profitabilitas sebagai variabel mediasi pengaruh manajemen modal kerja terhadap nilai perusahaan. Berdasarkan penjelasan tersebut, hipotesis 4, 5 dan 6 dapat dirumuskan sebagai berikut:

$\mathrm{H}_{4}$ : Profitabilitas dapat menjadi mediasi pengaruh Days Of Sales Outstanding terhadap Nilai Perusahaan

$\mathrm{H}_{5}$ : Profitabilitas dapat menjadi mediasi pengaruh Days of Sales Inventory terhadap Nilai Perusahaan

$\mathrm{H}_{6}$ : Profitabilitas dapat menjadi mediasi pengaruh Days Of Payable terhadap Nilai Perusahaan

\section{DATA DAN METODE}

Jenis penelitian ini adalah eksplanatori melalui pendekatan kuantitatif. Penelitian ini dilakukan pada perusahaan semen yang listing di Bursa Efek Indonesia (BEI) dalam enam periode (2012-2017). Dalam penelitian ini digunakan pendekatan non probability sampling dengan metode sampel jenuh, artinya semua populasi, enam peru- 
sahaan dijadikan sampel penelitian. Pengumpulan data dalam penelitian ini menggunakan metode dokumentasi. Uji hipotesis dan analisis menggunakan Partial Least Square (PLS) dan untuk uji variabel mediasi menggunakan uji Sobel.

\section{HASIL}

Variabel days of sales outstanding memiliki rata-rata yaitu 47 hari dengan standard deviasi 17,185 . Secara umum, kebijakan days of sales outstanding yang diterapkan perusahaan sudah baik dimana industri semen membutuhkan waktu sekitar 47 hari untuk merubah piutangnya menjadi kas kembali. Variabel days of sales inventory memiliki rata-rata yaitu 61 hari dengan standard deviasi 31,738. Secara umum, kebijakan days of sales inventory yang diterapkan perusahaan sudah baik dimana industri semen membutuhkan waktu sekitar 61 hari untuk merubah persediaannya menjadi kas kembali. Variabel days of payable memiliki rata-rata yaitu 69 hari dengan standard deviasi 30,349. Secara umum, kebijakan days of payable yang diterapkan perusahaan sudah baik dimana industri semen membutuhkan waktu sekitar 69 hari untuk menahan kasnya guna pelunasan hutang lancarnya.

Variabel profitabilitas memiliki rata-rata yaitu $12,89 \%$ dengan standard deviasi 5,019. Ini berarti, kemampuan industri semen dalam menghasilkan laba dari total assetnya yaitu sebesar $12,89 \%$. Variabel nilai perusahaan memiliki ratarata yaitu 6,16\% dengan standard deviasi 6,318. Perusahaan dengan nilai Tobin's $Q>1$ menunjukkan bahwa saham tersebut layak untuk dibeli.

Hasil uji linieritas dengan uji kurva menunjukkan hubungan antara variabel bebas dan variabel terikat adalah linier yang ditunjukkan dari nilai probabilitas masing-masing hubungan yang lebih kecil dari alpha 5\% $(0,05)$ sehingga asumsi linieritas terpenuhi. Tahap selanjutnya adalah uji hipotesis untuk menguji hubungan variabel dependen dan independen yang dikembangkan sesuai dengan model.

Berdasarkan analisis data, diperoleh koefisien jalur yang ditunjukkan pada tabel 1. Tabel 1 menunjukkan bahwa pengaruh antara days of sales outstanding (X1) dan profitabilitas (Z) memiliki nilai -0,098 dengan T-statistik 6,6449. Hubungan days of sales inventory (X2) dan profitabilitas $(Z)$ memiliki nilai 0,018 dengan $T$ statistik 7,560, sedangkan days of payable (X3) dengan profita-bilitas (Z) -0,089 dengan T-statistik 5,627 .

Tabel 1. Hasil Pengujian Pengaruh antar Variabel dengan Path Analysis

\begin{tabular}{rrrrrc}
\hline Hipotesis & Pengaruh & Koefisien & Std, Error & T Statistik & Keterangan \\
\hline 1 & $\mathrm{X}_{1}-\mathrm{Z}$ & $-0,098$ & 0,052 & 6,649 & Signifikan \\
2 & $\mathrm{X}_{2}-\mathrm{Z}$ & 0,018 & 0,050 & 7,560 & Signifikan \\
3 & $\mathrm{X}_{3}-\mathrm{Z}$ & $-0,089$ & 0,073 & 5,627 & Signifikan \\
4 & $\mathrm{X}_{1}-\mathrm{Z}-\mathrm{Y}$ & $-0,5102$ & 0,064 & 4,146 & Signifikan \\
5 & $\mathrm{X}_{2}-\mathrm{Z}-\mathrm{Y}$ & 0,6145 & 0,058 & 3,305 & Signifikan \\
6 & $\mathrm{X}_{3}-\mathrm{Z}-\mathrm{Y}$ & 0,7231 & 0,030 & 2,065 & Signifikan \\
\hline
\end{tabular}

Sementara itu, secara tidak langsung hubungan days of sales outstanding dengan nilai perusahaan melalui profitabilitas $-0,5102$ dan Tstatistik 4,146. Hubungan days of sales inventory secara tidak langsung dengan nilai perusahaan melalui profitabilitas 0,6145 dan T-statistik 3,305. Hubungan days of payable secara tidak langsung dengan nilai perusahaan melalui profitabilitas 0,7231 dan T-statistik 2,065. Sehingga dapat disimpulkan bahwa semua hipotesis diterima.

\section{PEMBAHASAN}

\section{Days of Sales Outstanding (DSO) terhadap Profitabilitas}

Hasil penelitian ini menunjukkan bahwa variabel days of sales outstanding secara signifikan berpengaruh negatif terhadap profitabilitas yang diproksikan oleh rasio return on asset (ROA). Pengaruh negatif ini menunjukkan bahwa semakin cepat periode penagihan piutang yang dilakukan oleh perusahaan, maka akan meningkatkan profitabilitas (ROA) perusahaan, begitu juga sebaliknya, semakin lama periode penagihan piutang akan menurunkan profitabilitas (ROA) perusahaan.

Hasil dari penelitian ini sesuai dengan pene-litian yang telah dilakukan oleh Rasyid et al. (2018), serta Shah \& Arif (2018) bahwa ada pengaruh yang signifikan antara days of sales outstanding terhadap profitabilitas perusahaan. Namun, pada penelitian terdahulu pengaruh days of sales outstanding bersifat positif, sedangkan hasil dari penelitian ini menunjukkan arah hubungan 
yang negatif atau berbanding terbalik. Afrifa \& Padachi (2016) dalam penelitiannya menjelaskan bahwa pada saat tertentu perusahaan dapat menambah modal kerjanya untuk meningkatkan tingkat labanya selama manfaatnya lebih besar daripada biaya implisitnya. Dijelaskan lebih lanjut oleh Afrifa \& Padachi (2016) bahwa untuk memberikan pelayanan yang baik dan menjaga hubungan hubungan baik kepada pelanggan, perusahaan dapat meningkatkan jumlah kredit kepada pelanggan.

\section{Days of Sales Inventory (DSI) terhadap Profitabilitas}

Hasil penelitian ini menunjukkan bahwa variabel days of sales inventory secara signifikan berpengaruh positif terhadap profitabilitas yang diproksikan oleh rasio return on asset (ROA), sehingga kebijakan perusahaan di dalam menentukan teknis produksi dan jangka waktu penjualan persediaan mempengaruhi tingkat profitabilitas (ROA) perusahaan. Pengaruh positif ini menunjukkan bahwa semakin lama periode konversi persediaan akan meningkatkan profitabilitas (ROA) perusahaan, begitu juga sebaliknya, semakin cepat periode konversi persediaan akan menurunkan profitabilitas (ROA) perusahaan. Selain itu, pengaruh yang signifikan tersebut menunjukkan bahwa perusahaan-perusahaan semen di Indonesia memperhatikan pengelolaan persediaan di dalam meningkatkan penjualan.

Hasil dari penelitian ini sesuai dengan penelitian yang telah dilakukan oleh (Kawakibi et al., 2019) (Gracia, 2018) Moeljadi (2017), Cumbie \& Donnellan (2017), dan Sudiyatno et al., 2017) bahwa ada pengaruh yang signifikan antara days of sales inventory terhadap profitabilitas perusahaan. Namun, pada penelitian terdahulu pengaruh periode konversi persediaan bersifat negatif, sedangkan hasil dari penelitian ini menunjukkan arah hubungan yang positif atau berbanding lurus.

\section{Days of Payables (DOP) terhadap Profitabilitas}

Hasil penelitian ini menunjukkan bahwa variabel days of payable secara signifikan berpengaruh negatif terhadap profitabilitas yang diproksikan oleh rasio return on asset (ROA). Pengaruh negatif ini menunjukkan bahwa semakin lama periode pelunasan hutang akan menurunkan profitabilitas (ROA) perusahaan, begitu juga sebaliknya, semakin cepat periode pelunasan hutang akan meningkatkan profitabilitas perusahaan. Selain itu, pengaruh yang signifikan ter- sebut menunjukkan bahwa perusahaan-perusahaan semen di Indonesia dengan tingkat profitabilitas yang tinggi tidak membutuhkan waktu yang lebih lama untuk melunasi hutang lancarnya. Temuan penelitian ini sesuai dengan penelitian yang dilakukan oleh Afrifa \& Padachi (2016), Lyngstadaas \& Berg (2016), dan Jakpar et al. (2017).

Penundaan pembayaran hutang yang dilaku-kan oleh perusahaan menunjukkan bahwa kondisi profitabilitas perusahaan kurang baik dan seba-liknya perusahaan yang profitabilitasnya baik akan lebih memilih untuk membayar hutangnya lebih cepat. Afrifa \& Padachi (2016) memiliki pen-dapat lain yaitu perusahaan kemungkinan memi-lih membayar hutangnya lebih cepat karena ada potongan harga dari pemasoknya.

\section{Days Of Sales Outstanding (DSO) Terhadap Nilai Perusahaan Melalui Profitabilitas}

Hasil penelitian menunjukkan bahwa days of sales outstanding berpengaruh signifikan negatif terhadap nilai perusahaan melalui profitabilitas. Hasil penelitian ini sejalan dengan penelitian terdahulu yang dilakukan oleh Rasyid et al. (2018) dan Shah \& Arif (2018) yang menyatakan bahwa sesuai dengan tujuan utama perusahaan yaitu memaksimalkan nilai kekayaan pemegang saham, semakin tinggi tingkat profitabilitas karena menerapkan efisiensi manajemen modal kerja melalui efisiensi penggunaan piutang, nilai perusahaan juga akan semakin meningkat. Penelitian ini membuktikan adanya pengaruh signifikan profitabilitas yang memediasi hubungan antar variabel sehingga pengujian ini memperkuat hubungan langsung antara days of sales outstanding terhadap nilai perusahaan.

\section{Days Of Sales Inventory (DSI) Terhadap Nilai Perusahaan Melalui Profitabilitas}

Temuan penelitian menunjukkan bahwa days of sales inventory berpengaruh signifikan positif terhadap nilai perusahaan melalui profitabilitas. Hasil penelitian ini sejalan dengan penelitian terdahulu yang dilakukan oleh Rasyid et al. (2018) dan Shah \& Arif (2018); (Mohamad, 2018) yang menyatakan bahwa sesuai dengan tujuan utama perusahaan yaitu memaksimalkan nilai kekayaan pemegang saham, semakin tinggi tingkat profitabilitas ka-rena menerapkan efisiensi manajemen modal kerja melalui efisiensi penggunaan persediaan, nilai perusahaan juga akan semakin meningkat. Penelitian ini membuktikan adanya pengaruh signifikan 
profitabilitas yang memediasi hubung-an antar variabel sehingga pengujian ini memper-kuat hubungan langsung antara days of sales inventory terhadap nilai perusahaan.

\section{Days Of Payable (DOP) Terhadap Nilai Perusahaan Melalui Profitabilitas}

Hasil penelitian menunjukkan bahwa days of payable berpengaruh dengan arah positif terhadap nilai perusahaan melalui profitabilitas. Hasil penelitian ini sejalan dengan penelitian terdahulu yang dilakukan oleh Naqi \& Siddiqui, (2020), Rasyid et al. (2018) dan Shah \& Arif (2018) yang menyatakan bahwa sesuai dengan tujuan utama perusahaan yaitu memaksimalkan nilai kekayaan pemegang saham, semakin tinggi tingkat profitabilitas karena me-nerapkan efisiensi manajemen modal kerja mela-lui penundaan pembayaran hutang, nilai peru-sahaan juga akan semakin meningkat. Penelitian ini membuk-tikan adanya pengaruh profitabilitas yang memediasi hubungan antar variabel sehing-ga pengujian ini memperkuat hubungan langsung antara days of sales inventory terhadap nilai peru-sahaan.

\section{SIMPULAN DAN SARAN}

Hasil penelitian ini menunjukkan bahwa manajemen modal kerja berpengaruh pada profitabilitas dan nilai perusahaan. Penerapan manajemen modal kerja yang baik membuat profitabilitas semakin meningkat dan seiring dengan meningkatnya profit maka nilai perusahaan juga meningkat. Profitabilitas secara tidak langsung dapat mendukung penerapan manajemen modal kerja dan nilai perusahaan. Ini mencerminkan asumsi investor kepada perusahaan yang menerapkan manajemen modal kerja yang baik mampu meningkatkan nilai perusahaan karena profit yang dihasilkan lebih tinggi.

Peneliti mencatat ada keterbatasan dalam penelitian ini. Pertama, ada informasi-informasi lain yang tidak dipublikasikan dalam laporan tahunan perusahaan sehingga tidak dapat dimasukkan dalam pengolahan data serta analisis dari masing-masing hubungan variabel. Kedua, hasil penelitian ini tidak cukup representatif untuk mewakili semua perusahaan publik di Indonesia. Oleh karena itu, penelitian lebih lanjut dapat menguji kembali model penelitian ini dalam konteks dan perspektif penelitian yang berbeda dan menggunakan model pengukuran yang berbeda. Bagi perusahaan semen, harus dapat menjalankan manajemen modal kerja yang efektif dan efisien untuk meningkatkan profit sehingga nilai perusahaan lebih baik. Hasil penelitian ini berkontribusi pada pentingnya manajemen modal kerja di subsektor semen dalam meningkatkan profit dan juga nilai perusahaan.

\section{DAFTAR PUSTAKA}

Abuzayed, B. (2012). Working Capital Management and Firm's Performance in Emerging Market: The Case of Jordan. International Journal of Managerial Finance, 8(2), 155-179.

Afrifa, G. A., \& Padachi, K. (2016). Working Capital Level Influence on SME Profitability. Journal of Small Business and Enterprise Development, 23(1), 44-63.

Agha, H., \& Mba, M. (2014). Impact Of Working Capital Management On Profitability. European Scientific Journal, 10(1).

Almeida, J. R. De, \& Junior, W. E. (2014). Access to Finance, Working Capital Management and Company Value: Evidences from Brazilian Companies Listed on BM\&FBOVESPA. Journal of Business Research, 67(5), 924-934.

Alsartawi, A. M. (2019). Board Independence, Frequency of Meetings and Performance. Journal of Islamic Marketing, 10(1), 290-303.

Brigham, E. F., \& Houston, J. F. (2018). Dasar-dasar manajemen keuangan (Edisi 14). Salemba Empat.

Caballero, S. B., Pedro J. García-Teruel, \& Solano, P. M. (2014). Working Capital Management, Corporate Performance and Financial Constraints. Journal of Business Research, 67(3), 332-338.

Chasbiandani, T., Rizal, N., \& Indra Satria, I. (2019). Penerapan Green Accounting Terhadap Profitabitas Perusahaan Di Indonesia. AFRE (Accounting and Financial Review), 2(2), 126-132. https://doi.org/10.26905/afr.v2i2.3722

Cheryta, A. M., Moeljadi, \& Indrawati, N. K. (2018). Leverage, Asymmetric Information, Firm Value, and Cash Holdings in Indonesia. Jurnal Keuangan Dan Perbankan, 22(1), 83-93.

Chowdhury, L. A. M., Rana, T., Akter, M., \& Hoque, M. (2018). Impact Of Intellectual Capital On Financial Performance: Evidence From The Bangladeshi Textile Sector. Journal of Accounting \& Organizational Change, 14(4), 429-454.

Cumbie, J. B., \& Donnellan, J. (2017). The Impact of Working Capital Components on Firm 
Value in US Firms. Journal of Economics and Finance, 9(8), 138-150.

Enqvist, J., Graham, M., \& Jussi Nikkinen. (2014). The Impact of Working Capital Management on Firm Profitability in Different Business Cycles: Evidence from Finland. Research in International Business and Finance, 32, 36-49.

Fama, E. F., \& Kenneth R. French. (2000). Testing Tradeoff and Pecking Order Predictions About Dividends and Debt. The Review of Financial Studies, 15(1), 1-33.

Fristiani, N. L., Pangastuti, D. A., \& Harmono, H. (2020). Intellectual Capital Dan Kinerja Keuangan Terhadap Nilai Perusahaan: Pada Industri Perbankan. AFRE (Accounting and Financial Review), 3(1), 35-42. https://doi.org/10.26905/afr.v3i1.4223

Gracia, E. (2018). Working Capital, Financial Constraints, and Firm Value: Evidence of Indonesia Manufacturing Firm. Journal of Economics and Business, 1(2), 171-176. https://doi.org/10.31014/aior.1992.01.02.16

Jakpar, S., Johari, A., \& Tinggi, M. (2017). Working Capital Management and Profitability: Evidence from Manufacturing Sector in Malaysia. Journal of Business \& Financial Affairs, 6(2), 1-9.

Kawakibi, A. A., Sumiati, \& Hadiwidjojo, D. (2019). The Effect of Working Capital Management on Company Profits And Values (Study of Cement Companies Listed on The Indonesia Stock Exchange). International Journal of Business, Economics and Law, 20(5), 244-261. https://doi.org/10.4018/978-1-4666-97232.ch013

Lin, W.-T., Horng, M.-S., \& Chou, J.-H. (2016). Relationship of Cash Conversion Cycle and PRGap With Firm Performance: An Empirical Study Of Taiwanese Companies. Investment Management and Financial Innovations, 13(3), 293-299.

Lyngstadaas, H., \& Berg, T. (2016). Working Capital Management: Evidence From Norway. International Journal of Managerial Finance, 12(3), 295-313.

Moeljadi. (2017). Financial Ratio Return on Equity dengan Net Profit Margin sebagai Variabel Moderator. Jurnal Perilaku Dan Strategi Bisnis, 5(2), 133-160.

Mohamad, N. E. A. (2018). Does Working Capital Relevant in Enhancing the Malaysia's Government Linked Company (GLC) value? Global Business and Management Research,
10(3).

http:/ / search.proquest.com.ezaccess.library. uitm.edu.my/docview/2159617982?accounti $\mathrm{d}=42518$

Naqi, A., \& Siddiqui, D. A. (2020). The Impact of Aggressive Working Capital Management Policy on Firm's Value: A Mediating Effect of Company's Profitability. SSRN Electronic Journal. https://doi.org/10.2139/ssrn.3683016

Putri, E. L., Haryanto, S., \& Firdaus, R. M. (2018). Mampukah Good Corporate Governance dan Risiko Kredit Sebagai Prediktor Financial Distress? AFRE (Accounting and Financial Review), 1(1). https://doi.org/10.26905/afr.v1i1.2291

Rasyid,R., Lukman, S., Husni, T., \& Adrimas. (2018). The Impact of Aggressive Working Capital Management Policy on Firm's Value: A Mediating Effect of Company's Profitability. Journal of Business and Management Sciences, 6(1), 16-21.

Sabrin, Sarita, B., Syaifuddin, D. T. D., \& Sujono. (2016). The Effect of Profitability on Firm Value in Manufacturing Company at Indonesia Stock Exchange. The International Journal Of Engineering And Science (IJES), 5(10), 81-89.

Shah, B., \& Arif, M. (2018). Working Capital Efficiency and Firm Value: Evidence form Pakistani Firms. Journal of Business $\mathcal{E}$ Financial Affairs, 7(1), 1-10.

Sin, H. N., Ye, C., Ong, T. S., \& Teh, B. H. (2017). The Impact of Working Capital Management on Firm's Profitability: Evidence from Malaysian Listed Manufacturing Firms. International Journal of Economics and Financial Issues, 7(3), 662-670.

Sudiyatno, B., Puspitasari, E., \& Sudarsi, S. (2017). Working Capital, Firm Performance, and Firm Value: An Empirical Study in Manufacturing Industry on Indonesia Stock Exchange. Economics World, 5(5), 1-9.

Sunday, E. O. (2017). Impact Of Working Capital On The Profitability Of Manufacturing Firms In Nigeria. Research Journal's Journal of Accounting, 5(2), 1-9.

Ukaegbu, B. (2014). The Significance of Working Capital Management in Determining Firm Profitability: Evidence from Developing Economies in Africa. Research in International Business and Finance, 31, 1-16.

Wasiuzzaman, S. (2015). Working Capital and Firm Value in an Emerging Market. 
AFRE Accounting and Financial Review Vol. 3 (2) 2020: 126-135

International Journal of Managerial Finance, 11(1), 60-79.

Wiyono, G. (2017). Efektifitas Manajemen Siklus Konversi Kas Perusahaan Sektor Aneka Usaha Terdaftar Di BEI. Ekuitas: Jurnal Ekonomi Dan Keuangan, 1(4), 451-471.

Yazdanfar, D., \& Öhman, P. (2014). The Impact of Cash Conversion Cycle on Firm Profitability: An Empirical Study Based on Swedish Data. International Journal of Managerial Finance, 10(4), 442-452. 